\title{
Multiple integration of the gene ganA into the Bacillus subtilis chromosome for enhanced $\beta$-galactosidase production using the CRISPR/Cas9 system
}

\author{
Hildegard Watzlawick ${ }^{*+}$ and Josef Altenbuchner ${ }^{\dagger}$
}

\begin{abstract}
The ganA gene from Bacillus subtilis encoding a $\beta$-galactosidase for degradation of the galactomannan was integrated in different loci of the B. subtilis chromosome employing the CRISPR/Cas9 system. Hereby a total of five copies of ganA cassettes in which the ganA gene was fused with the glucitol-promoter were inserted in the recipient chromosome wherein hypothetical, sporulation and protease genes were deleted. The strain with five copies of ganA expression cassette showed a $\beta$-galactosidase activity similar to the one with the same gene on a pUB110 derived multi-copy plasmid and under the same regulatory control of the glucitol promoter and GutR activator. The production of $\beta$-galactosidase in the strain with the multi-copy plasmid decreased rapidly when growth was performed under induced conditions and without antibiotic selection. In contrast, the strain with the five copies of ganA in the chromosome produced $\beta$-galactosidase for at least 40 generations. This demonstrates that the CRISPR/Cas 9 system is a valuable and easy tool for constructing stable producer strains. The bigger efforts that are needed for the multiple target gene integration into the chromosome compared to cloning in expression vectors were justified by the higher stability of the target genes and the lack of antibiotic resistance genes.
\end{abstract}

Keywords: Bacillus subtilis, Multiple integration, CRISPR-Cas9 genome editing, Bacillus subtilis $\beta$-galactosidase

\section{Introduction}

The production of recombinant proteins in high yield and high quality is a major task in biotechnology. Hereby, bacterial expression systems (Terpe 2006) are attractive because of the rapid cell growth to high cell densities in inexpensive media. The most commonly used host is $E$. coli due to their easy handling, the wealth of knowledge and the large repertoire of expression vectors. Other important industrial microorganisms are Bacilli. More than one-third of industrial enzymes are produced by Bacillus strains (Meissner et al. 2015). For heterologous gene expression the Gram-positive B. subtilis has a long

\footnotetext{
*Correspondence: Hildegard.Watzlawick@iig.uni-stuttgart.de ${ }^{\dagger}$ Hildegard Watzlawick and Josef Altenbuchner contributed equally to this work

Institute of Industrial Genetics, University of Stuttgart, Allmandring 31, 70569 Stuttgart, Germany
}

history of industrial use and is widely appreciated as a cell factory (Cai et al. 2019; Jeong et al. 1998; Liu et al. 2013; Schallmey et al. 2004). It is regarded as "Generally Recognized As Safe" (GRAS) for its lack of endotoxins and is used as a food-grade expression host (de Boer Sietske and Diderichsen 1991). Under stress conditions cells develop a competence status which allows highly efficient uptake of DNA for genetic engineering (Chen and Dubnau 2004; Claverys et al. 2006; Kramer et al. 2007). There are two strategies available for overproduction of recombinant proteins, one is the cloning of the target gene into expression vectors and the other one is to integrate the target gene under a strong promoter into the chromosome. There is a large repertoire of vectors available and the use of high copy vectors ensures high protein production (Brockmeier et al. 2006; Heravi et al. 2015; Schumann 2007; Xia et al. 2007). A drawback of these vectors, based mostly on rolling circle replication is their structural and 
segregation instability (Fleming and Patching 1994; Shoham and Demain 1991) and the need of antibiotics for selection of plasmid maintenance. The integration of the target gene into the chromosome ensures high stability but due to the single copy of the gene gives less yield of product (Janniere et al. 1985; Mori et al. 1988; Motejadded and Altenbuchner 2007). This limitation can be overcome by integration of tandemly amplified target genes or by integration of multiple copies of the target gene at various positions of the chromosome (Huang et al. 2017; Kiel et al. 1995; Petit et al. 1990, 1992; Slugeňová et al. 1993; van der Laan et al. 1991; Wang et al. 2004; Yomantas et al. 2011; Young 1984). Tandemly amplified copies of genes are unstable as well (Petit et al. 1992; van der Laan et al. 1991; Young 1984), although there are other studies reporting high stability of the amplicons (Janniere et al. 1985; Vázquez-Cruz et al. 1996). Nevertheless, the integration of genes at multiple loci is the most promising way to achieve high yield and stable productivity. The antibiotic resistance genes necessary for selection of the integration events can be removed either by site-specific recombination (Bloor and Cranenburgh 2006; Sanchez et al. 2007; Sanchis et al. 1997) or avoided by using markerless systems (Kostner et al. 2017; Wenzel and Altenbuchner 2015; Zakataeva et al. 2010; Zhang et al. 2006). The Clustered, Regular Interspaced Short Palindromic Repeat (CRISPR) system with Cas9 as targeted nuclease was recently adapted for its use in B. subtilis (Altenbuchner 2016; Burby and Simmons 2017; Hong et al. 2018; Westbrook et al. 2016) and speculated to be ideal for multiple gene integration into the B. subtilis chromosome. It allows precise deletions and insertions without leaving behind antibiotic resistance genes and other scares such as recognition sites for site-specific recombinases. Irrespective of the methods used for target integration another important question to consider are the integration sites. They should not influence growth and protein production. In an attempt to reduce the $B$. subtilis genome it has been shown that there are hundreds of genes and large chromosomal regions which can be deleted without a negative influence on cell growth (Aguilar Suárez et al. 2019; Commichau et al. 2013; Manabe et al. 2012, 2013; Morimoto et al. 2008; Reuß et al. 2017; Tanaka et al. 2013). Concomitant deletions and insertions even offer the possibility to remove unwanted gene products like proteases and properties like sporulation or prophages.

As a proof of principle we integrated the $\operatorname{gan} A$ gene from $B$. subtilis encoding a $\beta$-galactosidase for degradation of the galactomannan (Watzlawick et al. 2016) five times into the $B$. subtilis chromosome and hereby deleted various hypothetical, sporulation and protease genes. Herby the ganA gene was fused with the glucitol promoter (Poon et al. 2001; Ye et al. 1994; Ye and Wong 1994) to generate a Pgut-ganA expression cassette. The strain with five copies of the ganA expression cassette showed a $\beta$-galactosidase activity similar to one with the same gene on a pUB110 derived multi-copy plasmid. In contrast to the multi-copy plasmid the $\beta$-galactosidase activity was stable for many generations even under induced conditions whereas the multi-copy plasmid was rapidly lost. This demonstrates that the CRISPR/Cas9 system is an efficient method to introduce genes multiple times into a bacterial chromosome for high and stable protein production.

\section{Materials and methods}

\section{Strains, media, and growth conditions}

Escherichia coli JM109 (Table 1) was used for plasmid propagation and gene expression throughout this study. $E$. coli strains containing the desired plasmids were selected on Luria-Bertani media (LB) plates supplemented with ampicillin $(100 \mu \mathrm{g} / \mathrm{ml})$ or kanamycin $(50 \mu \mathrm{g} /$ $\mathrm{ml}$ ) depending on the plasmid selection marker. For blue/ white screening IPTG $(50 \mu \mathrm{g} / \mathrm{ml})$ and X-Gal $(80 \mu \mathrm{g} / \mathrm{ml})$ was added. B. subtilis cells were grown on LB plates as well, for selection of plasmids kanamycin was added at $5 \mu \mathrm{g} / \mathrm{ml}$. B. subtilis REG19 is derived from B. subtilis 168 and contains an additional copy of the comK and comS gene under control of the $B$. subtilis mannitol promoter (Rahmer et al. 2015). Step by step, five different gene deletions and concomitant insertions of gan $A$ under control of the gut promoter $P_{g u t}$, were introduced in REG19 to obtain the strains JA-Bs34, JA-Bs35, JA-Bs36, JA-Bs37 and JA-Bs40 (see Table 1). For induction of ganA expression, the overnight cultures in LB with $0.5 \%(\mathrm{w} / \mathrm{v})$ glucose were diluted to $0.05 \mathrm{OD}_{600}$ in $10 \mathrm{ml} \mathrm{LB}$ with $0.5 \%(\mathrm{w} / \mathrm{v})$ glucitol and for repression of ganA strains were grown in LB with $0.5 \%$ glucose. The cells were incubated in shake flasks at $37{ }^{\circ} \mathrm{C}$ and $200 \mathrm{rpm}$ on a shaking platform. In case of REG19/pHWG1132 kanamycin was supplemented in the medium for the preculture and during induction. After $16 \mathrm{~h}$ the cells were harvested by centrifugation.

\section{Construction of plasmids}

The plasmid pJOE8386.1 is a shuttle vector including the origin of replication and the kanamycin resistance gene of pUB110 (Jalanko et al. 1981) the origin and the ampicillin resistance of pIC20HE (Altenbuchner et al. 1992). The plasmid carries an expression cassette consisting of an enhanced green fluorescent protein (eGFP) gene fused with the translation initiation region of $g s i B$ (Wenzel et al. 2011) and the gut promoter, both from B. subtilis. In addition, Rho-independent transcription terminators were introduced upstream of the gut promoter and downstream of eGFP to avoid transcription 
Table 1 Strains used in this study

\begin{tabular}{|c|c|c|}
\hline Strain or plasmid & Genotype or relevant structure & Source or references \\
\hline \multicolumn{3}{|l|}{ E. coli } \\
\hline JM109 & 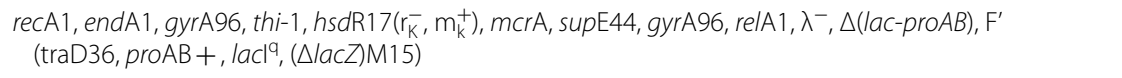 & Yanisch-Perron et al. (1985) \\
\hline \multicolumn{3}{|l|}{ B. subtilis } \\
\hline Reg19 & $\operatorname{trpC2}, \triangle m a n P A:: e r m C, P_{m t / A}$-comK-coms & Rahmer et al. (2015) \\
\hline$J A-B s 34$ & $\operatorname{trp} C 2, \triangle m a n P A:: e r m C, P_{m t \mid A} C o m K-c o m S, \triangle\left(s p o l / S A\right.$, spollSB) ::. $P_{\text {gut }}-$ ganA & This study \\
\hline$J A-B s 35$ & 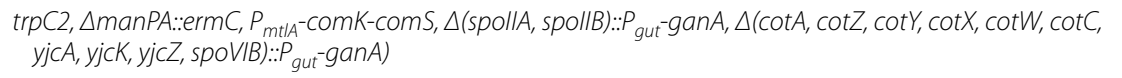 & This study \\
\hline JA-Bs36 & 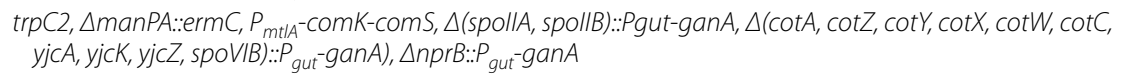 & This study \\
\hline$J A-B s 37$ & 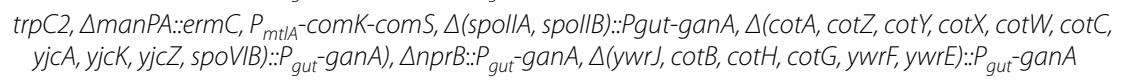 & This study \\
\hline$J A-B s 40$ & 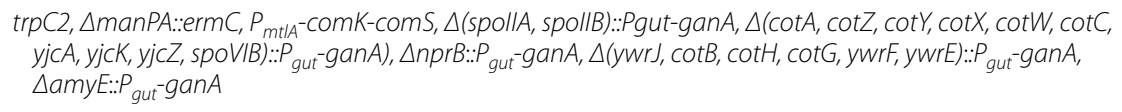 & This study \\
\hline
\end{tabular}

read-through from vector promoters into the eGFP gene and read-through from the gut promoter into vector sequences (see Fig. 1). The ganA gene was amplified by polymerase chain reactions (PCR) from chromosomal DNA of B. subtilis with oligonucleotides s9872 and s9873 (Table 2) and inserted between the BamHI and BsrGI site of pJOE8386.1 to get pHWG1132. Hereby eGFP was deleted and the ganA gene without the translation start codon was fused to the first six codons of gsiB and the two codons provided by the BamHI site (Fig. 1).

All CRISPR/Cas9 vectors for insertion of Pgut-ganA into the $B$. subtilis chromosome were constructed in the same way as will be demonstrated for pJOE9898.1. A 20 nucleotide spacer sequence for guiding the Cas9 to the target site was selected from gene spoIIA using the software CCTop (Stemmer et al. 2015). The two complementary oligonucleotides were modified by adding four bases to the $5^{\prime}$ ends to fit to the single-strand ends generated by cutting pJOE8999.1 by BsaI (see oligonucleotides s12531/ s12532, Table 2). The oligonucleotides were annealed by heating to $95{ }^{\circ} \mathrm{C}$ for $5 \mathrm{~min}$, and slowly cooling down to room temperature and ligated to $B s a \mathrm{I}$ cut vector pJOE8999.1. Colonies with cloned spacers were identified by blue-white screening on LB plates supplemented with ampicillin, IPTG and X-Gal. Plasmid DNA from white colonies were isolated and sequenced with the primer s11222 (see Table 2). The verified new plasmid was cut with $S m a \mathrm{I}$ and $S f i \mathrm{I}$ and three SfiI-fragments were ligated with the vector DNA at the same time, consisting of two PCR fragments from the flanking regions obtained with primers s9732N/s9733N and s9734N/s9735N and the expression cassette obtained by PCR from pHWG1132 with primers s12799/s12800. The ligation was done overnight at room temperature in $10 \mu \mathrm{l}$ volume with $100 \mathrm{ng}$ vector DNA, $20 \mathrm{ng}$ of each flanking fragments and $40 \mathrm{ng}$ of the expression cassette fragment. The different SfiI sites at the ends of the various fragments and vector allowed the ordered cloning of the three fragments. The other plasmids (pJOE9899.2, pJOE9918.5, pJOE9957.1 and pJOE9974.2) were constructed in the same way using primers shown in Table 2.

\section{DNA transformation}

Standard molecular techniques, such as E. coli transformation, were carried out as described by Sambrook and Russell (2001). Induction of competence and transformation of B. subtilis Reg19 was performed as described before (Rahmer et al. 2015). In brief, an overnight culture of REG19 cultivated in LB, was diluted to an optical density of $0.05 \mathrm{OD}_{600}$ in $9 \mathrm{ml} \mathrm{LB}$ and incubated in a $100 \mathrm{ml}$ shake flask at $37^{\circ} \mathrm{C}$ for $1.5 \mathrm{~h}$ at $200 \mathrm{rpm}$. Competence was induced by adding $1 \mathrm{ml} \mathrm{LB}$ containing $5 \%(\mathrm{w} / \mathrm{v})$ mannitol and further incubation for another $1.5 \mathrm{~h}$. The cells were washed by centrifugation (Sorvall Megafuge, $4500 \mathrm{rpm}$, room temperature) and resuspended in the same volume of LB. To $1 \mathrm{ml}$ culture about $500 \mathrm{ng}$ plasmid DNA was added and the cells incubated at $37^{\circ} \mathrm{C}$ for $1 \mathrm{~h}$ in case of pHWG1132 and in case of pJOE8999 and derivatives at $30{ }^{\circ} \mathrm{C}$ for $1.5 \mathrm{~h}$. Finally, the cells were plated on LB agar plates containing $5 \mu \mathrm{g} / \mathrm{ml}$ kanamycin and incubated overnight at $37^{\circ} \mathrm{C}$ or $30^{\circ} \mathrm{C}$ depending on the plasmid used.

\section{DNA techniques}

The desired DNA fragments were amplified by PCR utilizing Q5 DNA polymerase (New England BioLabs ${ }^{\circledR}$, Frankfurt am Main, Germany) on a PTC-200 Peltier Thermal Cycler (MJ Research). Oligonucleotides obtained from Eurofins MWG and used in this 


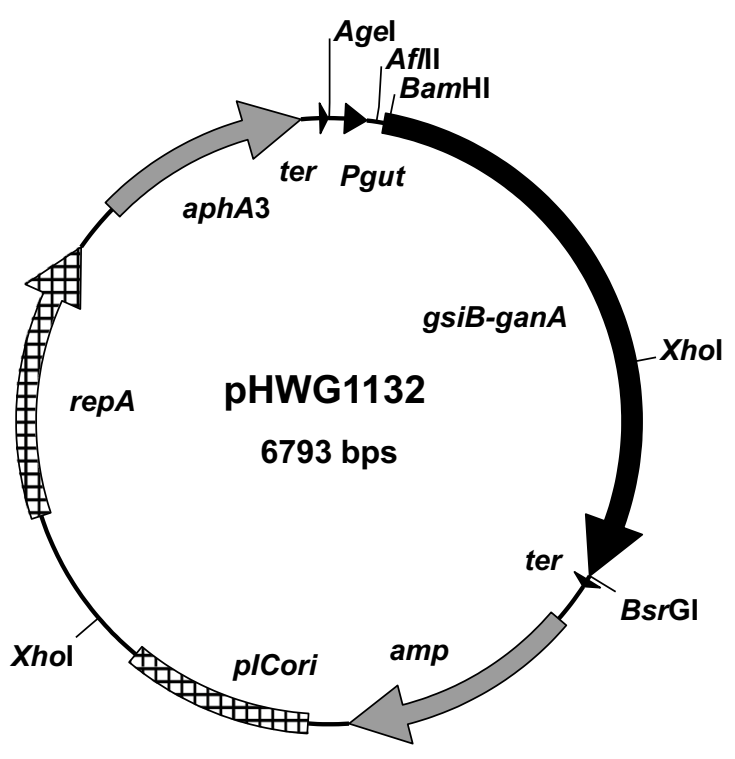

AgeI

ACCGgTCCTCCTATtAgtACTATtTTATCAATCCAGCGTTTTTTGTATA

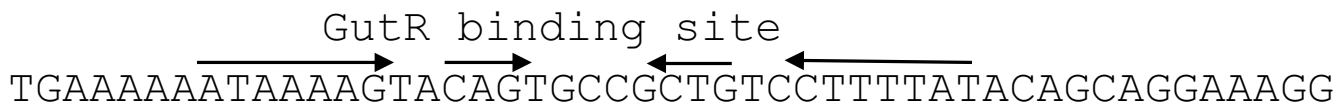

$$
-35-10 \quad+1 B g 1 I I
$$

CTGTTGAACGTGTTAAAAAGCAGATAAAATGGGGGCAGATCTTATTATT

XbaI AfIII RBS ECORI

CACAсттTCTAGAAATATTTTCTTAAGAATTAAAGGAGGAATTCAAAA

$$
B a m H I \longmapsto \operatorname{ganA}
$$

TGGCAGACAATAACAAAGGATCCTCA

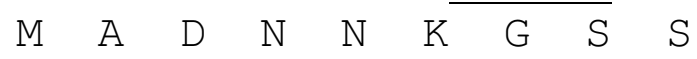

Fig. 1 Restriction map of the expression vector pHWG1132 and the transcription and translation initiation region of ganA consisting of the gut promoter with the GutR binding site (arrows) and the $-35,-10$ and +1 sequence (grey blocks). The sequence derived from gsiB is shown in italics, the ATG start codon in bold letters and restriction sites are underlined. The sequence between the Bg/ll site and Afll site is derived from vector PJOE5751.1

study are listed in Table 1. Commercial kits including DNeasy ${ }^{\circledR}$ Blood \& Tissue Kit (Cat. \#69506; Qiagen, Hilden, Germany) for chromosomal DNA extraction, "innuPREP Plasmid mini Kit" (Analytic Jena AG, Jena, Germany) for plasmid isolation and "NucleoSpin ${ }^{\circledR}$ Gel and PCR Clean-up" kit (Machery-Nagel, Düren,
Germany) for PCR fragment purification were applied through-out this study. Restriction enzymes were provided by New England BioLabs ${ }^{\circledR}$ (Frankfurt am Main, Germany). T4 DNA Ligase was purchased from Thermo Fisher Scientific Inc. (Karlsruhe, Germany). Plasmid DNA was sequenced by GATC Biotech (Konstanz, Germany). 
Table 2 Oligonucleotides used

\begin{tabular}{|c|c|c|}
\hline Number & Sequence $^{a}$ & Purpose \\
\hline S9732N & 5'-aaggccaacgaggccAGCAGATGCTGCAGC & Construction of pJOE9898.1 flanking sequences \\
\hline S9733N & 5'-aaggccagtctggccGATCAGCTTAATTGCGCTG & \\
\hline S9734N & 5'-aaggcctaaatggccGACAGAAGCGGTGTGAC & \\
\hline S9735N & 5'-aaggccttattggccGTCGGAGCAATGACGTTTA & \\
\hline S12531 & 5'-tacgGAATCCCTCACATCTGAAAT & Construction of pJOE9898.1 spacer \\
\hline S12532 & 5'-aаacATTTCAGATGTGAGGGATTC & \\
\hline S12618 & 5'-GAAGCACTGATTCTATCACC & Colony PCR to prove the deletion by pJOE9898.1 \\
\hline S12619 & 5'-CATCCAGCCATTCAAATTGA & \\
\hline S9703N & 5'-aaggccaacgaggccACTTGAAGGCCGTAACATT & Construction of pJOE9899.1, flanking sequences \\
\hline S9704N & 5'-aaggccagtctggccTGCTTAGCGGGCAGT & \\
\hline S9705N & 5'-aaggcctaaatggccTGTTAATGATGCAAGGGCT & \\
\hline S9706N & 5'-aaggccttattggccCGGCGTCCAATCGTTTTAC & \\
\hline S12533 & 5'tacgAGAATTAGAAGATAAAATTG & Construction of pJOE9899.1, spacer \\
\hline S12534 & 5'-aаacCAATTTTATCTTCTAATTCT & \\
\hline S12620 & 5'-CAGAGGACTGTACCATGAT & Colony PCR to prove the deletion by pJOE9899.1 \\
\hline S12619 & 5'-CATCCAGCCATTCAAATTGA & \\
\hline S9724N & 5'-aaggccaacgaggccCAGGAAGCTGTTGAATCT & Construction of pJOE9918.1, flanking sequences \\
\hline S9725N & 5'-aaggccagtctggccGCCCTTCTTTTTCTACTCTA & \\
\hline S9726N & 5'-aaggcctaaatggccGCTCATTTTCTTAAAAAGAATATC & \\
\hline S9727N & 5'-aaggccttattggccGGCGATAAAGAATTCGAAG & \\
\hline S12529 & 5'-tacgGCAATCAGCTTCAGTCGAAA & Construction of pJOE9918.1, spacer \\
\hline S12530 & 5'-aаaсTTTCGACTGAAGCTGATTGC & \\
\hline S12660 & 5'-CGGCCTGTTGAATATTAAAC & Colony PCR to prove the deletion by pJOE9918.1 \\
\hline S12619 & 5'-CATCCAGCCATTCAAATTGA & \\
\hline S9707N & 5'-aaggccaacgaggccCATGATGTTTGTCCCTAG & Construction of pJOE9957.1, flanking sequences \\
\hline S9708N & 5'-aaggccagtctggccGTTTCATACTGTGCTAAAGA & \\
\hline S9709N & 5'-aaggcctaaatggccGTACCCTATAGTTATTTAAATCC & \\
\hline S9710N & 5'-aaggccttattggccCCCAAATCGAACACGGTTCA & \\
\hline S12649 & 5'-tacgATGTCAGCAATACACACAAA & Construction of pJOE9957.1, spacer \\
\hline S12650 & 5'-aaacTTTGTGTGTATTGCTGACAT & \\
\hline S12715 & 5'-GAATGCATCCACAGCAGG & Colony PCR to prove the deletion by pJOE9957.1 \\
\hline S12716 & 5'-GGCATAAATCACAGTGGCA & \\
\hline S9795 & 5'-aaggccaacgaggccGGGCTTGTCTTTATCGTG & Construction of pJOE9974.1, flanking sequences \\
\hline S9796 & 5'-aaggccagtctggccGATGTGAAGACTGGAG & \\
\hline S9797 & 5'-aaggcctaaatggecGCCTGGCTTTGATTACGTG & \\
\hline S9798 & 5'-aaggccttattggccGTGCTCTCCGATAATATGC & \\
\hline S12673 & 5'-tacgGCTTATATCTATAAACATGA & Construction of pJOE9974.1, spacer \\
\hline S12674 & 5'-aaacTCATGTTTATAGATATAAGC & \\
\hline S12740 & 5'-CGGTAAGTCCCGTCTAGC & Colony PCR to prove the deletion by pJOE9974.1 \\
\hline S12741 & 5'-GGGAAGCGTTCACAGTTTC & \\
\hline S12799 & 5'-aaggccagactggccTAAAAGTACAGTGCCGCTG & Amplification of Pgut-ganA \\
\hline S12800 & 5'-aaggccatttaggccCCGAAAAGTGCCACCTG & \\
\hline S10494 & 5'-GACCTCAAAAAGGTCTTTA & DNA sequencing of inserts in pJOE8999.1 \\
\hline S11222 & 5'-CACGCATTGATTGAGTCAG & \\
\hline
\end{tabular}

\footnotetext{
a Small letters: nucleotides added for cloning
} 
Insertion of $P_{\text {gut }}{ }^{-}$ganA into the $B$. subtilis chromosome and curing of the plasmids

Plasmid DNA (about $500 \mathrm{ng}$ in $10 \mu \mathrm{l}$ ) was added to competence induced REG19 (1 ml) and the cells were incubated at $30{ }^{\circ} \mathrm{C}$ for $1.5 \mathrm{~h}$ on a roller drum and then plated on LB agar supplemented with kanamycin at $30{ }^{\circ} \mathrm{C}$ for 2 days. Colonies were streaked out on LB agar plates with kanamycin and $0.5 \%$ mannose to induce cas 9 expression. For plasmid curing, cells were then streaked out on LB agar plates at $50{ }^{\circ} \mathrm{C}$ and after growth streaked out again to single colonies on LB agar plates at $42{ }^{\circ} \mathrm{C}$. Finally, cells were tested at $30{ }^{\circ} \mathrm{C}$ on $\mathrm{LB}$ plates supplemented with kanamycin for loss of the plasmid and by colony PCR for correct insertion/deletions within the chromosome (see Table 2).

\section{Measurement of $\beta$-galactosidase activity}

After the growth of the cells for $16 \mathrm{~h}$ in LB media containing either glucitol or glucose, a volume containing $10 \mathrm{OD}_{600}$ of cells (approximately $1 \times 10^{10}$ cells) were harvested by centrifugation and the cell pellet was resuspended in $1 \mathrm{ml} 0.1 \mathrm{M}$ potassium phosphate buffer, $\mathrm{pH}$ 6.5. Crude cell extract was prepared using ultrasonic sound ( $3 \times 45$ s, $50 \%$ duty cycle; Heat Systems-Ultrasonics, Inc. model W-385 sonicator, Farmingdale, New York, USA). After centrifugation, the supernatant of the lysate (cleared lysate) was used for the enzyme assay. The activity of $\beta$-galactosidase was determined by measuring the rate of $p$-nitrophenyl $\beta$-D-galactopyranoside ( $\mathrm{pNP}-\beta \mathrm{Gal}$ ) hydrolysis as described earlier (Watzlawick et al. 2016). One unit of the enzyme activity was defined as the release of $1 \mu \mathrm{mol}$ of pNP per minute at $37^{\circ} \mathrm{C}$. Protein concentration was determined by the method of Bradford (1976) with bovine serum albumin as a standard. SDS-PAGE was done according to the method of Lämmli (1970).

\section{Results}

Construction of the expression vector pHWG1132 and five different CRISPR/Cas9 vectors for integration of ganA into the $B$. subtilis chromosome

The expression vector pHWG1132 (Fig. 1) is a shuttle vector consisting of the replication origin and the kanamycin resistance gene of pUB110 and the replication origin and the ampicillin resistance gene of pIC20HE. In addition, it contains the expression cassette of $\operatorname{gan} A$, where the ganA gene of $B$. subtilis was under control of the B. subtilis glucitol promoter $\left(P_{g u t}\right)$ and flanked by rho-independent transcriptional terminators upstream of $P_{g u t}$ and downstream of ganA. Between gut promoter and $g a n A$ the translation initiation sequence of gsi $B$ was inserted for efficient translation of $\operatorname{gan} A$. With this plasmid the B. subtilis strain REG19, containing a second copy each of the competence genes comK-comS genes under the mannitol promoter, was transformed as described (Rahmer et al. 2015).

For integration of the $P_{g u t}$-ganA expression cassette into $B$. subtilis chromosome five regions within the chromosome were selected (Barbe et al. 2009) which were supposed to allow integration of $\operatorname{ganA}$ as well deletion of genes at the integration sites without affecting growth of the strains (Zhu and Stülke 2018). In strain JA-Bs34 the $P_{\text {gut }}$-ganA cassette was integrated between $x y l A$ and pit. Hereby the genes spoIISA and spoIISB were deleted (see Fig. 2). In JA-Bs35 the expression cassette was integrated between $f a b I$ and $y j c D$ deleting 10 genes from $\cot A$ to spoVIF. In JA-Bs36 the cassette was integrated between $y i t R$ and $y i t S$ deleting the protease encoding gene nprB. JA-Bs37 had the expression cassette integrated between $y w r K$ and $y w r D$ producing a deletion of six genes from $y w r J$ to $y w r E$ and finally in JA-Bs40 the expression cassette was integrated between $y c g B$ and $l d h$ replacing $a m y E$. The CRISPR/Cas9 vectors were constructed in the following way. First, a spacer sequence was cloned into the CRISPR/Cas9 vector pJOE8999, targeting Cas9 to the region which should be deleted during integration. The $P_{g u t}-g a n A$ sequence from pHWG1132 was amplified by PCR with oligonucleotides containing SfiI sites at the ends. In addition 700-800 bp sequences flanking the insertion sites and having compatible $S f i$ sites to the vector and the $P_{\text {gut }}$-ganA cassette were amplified by PCR as well and the vector and the three PCR fragments were ligated in one step. The CRISPR/Cas9 vectors pJOE9898.1, pJOE9899.2, pJOE9918.5, pJOE9957.1 and pJOE9974.2 generated in this way were used to transform REG19, one after the other to insert the $P_{g u t}-$ gan $A$ expression cassette five times into the $B$. subtilis chromosome (Fig. 2).

\section{Production of GanA}

The GanA activity was determined with the synthetic substrate $p$-nitrophenyl- $\beta$-D-galactopyranoside (pNP$\beta \mathrm{Gal})$. Cells of a stationary overnight culture in LB were diluted to an optical density of $0.05 \mathrm{OD}_{600}$ in $\mathrm{LB}$ with $0.5 \%$ glucitol and grown in baffled shaking flasks at $200 \mathrm{rpm}$ and $37{ }^{\circ} \mathrm{C}$ for $16 \mathrm{~h}$. The cells were harvested by centrifugation, resuspended in $0.1 \mathrm{M}$ sodium phosphate buffer $\mathrm{pH} 6.5$ and lysed by ultrasonication. The GanA activity of the cleared crude cell extract was determined with pNP- $\beta$ Gal as substrate. The specific $\beta$-galactosidase activities in units per mg protein obtained are shown in Fig. 3. The strain REG19 contains already one copy of $\operatorname{ganA}$ within the gan-operon. This gene is only transcribed from its native gan promoter by induction with galactan (Watzlawick et al. 2016). Therefore, this copy in REG19 produced nearly no activity under the used conditions in contrast to the second copy in JA-Bs34, 


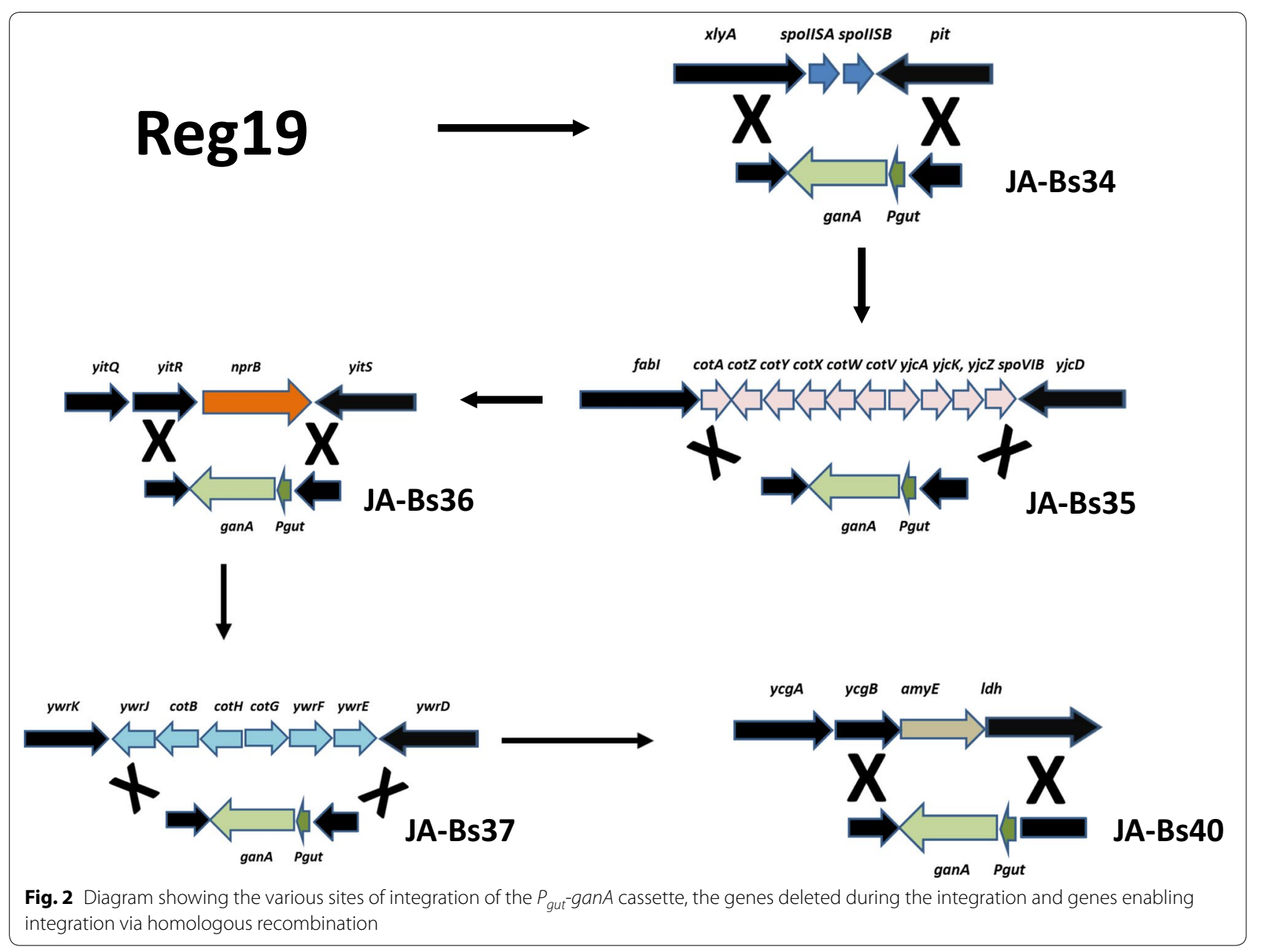

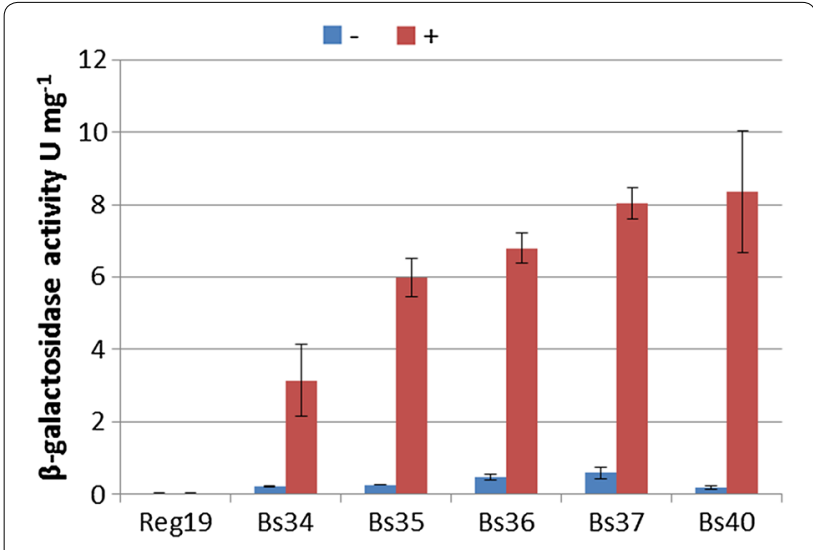

Fig. 3 GanA B-galactosidase activity in cleared crude extracts from B. subtilis containing none (REG19), 1 copy (JA-Bs34), 2 copies (JA-Bs35), 3 copies (JA-Bs36), 4 copies (JA-Bs37) and 5 copies (JA-Bs40) of the $P_{\text {qut }}$-ganA cassette. The cells were grown in LB with either $0.5 \%$ glucitol (+) or $0.5 \%$ glucose $(-)$ and after $16 \mathrm{~h}$ crude cell extract was prepared for determining $\beta$-galactosidase activity and protein concentration. The values are the mean of three different experiments now under the gut promoter. In the strain JA-Bs35 this activity was duplicated. In JA-Bs36, JA-Bs37 and JA-Bs40 with 3,4 and 5 copies respectively, the $\beta$-galactosidase activity increased as well but at a lower rate as expected. The strain JA-Bs40 showed an activity in the same range $(8.36 \pm 1.19 \mathrm{U} / \mathrm{mg})$ as it was determined with glucitolinduced REG19/pHWG1132 cells $(9.83 \pm 1.15 \mathrm{U} / \mathrm{mg})$. In the strains grown with glucose the $\beta$-galactosidase activity was about 20 -fold lower as expected from an inducible promoter underlying in addition catabolite repression (Görke and Stülke 2008). The SDS-Page with the crude extracts from the various strains (Fig. 4) showed an increasingly prominent protein band of $79.8 \mathrm{kDa}$ which corresponds to the molecular weight of GanA.

\section{Comparing the stability of JA-Bs40 and REG19 pHWG1132 concerning GanA production}

The stability of strain JA-Bs40 and REG19/pHWG1132 in the production of GanA under ganA induced conditions (adding of glucitol) and without antibiotic 


\section{$\underline{\mathrm{kDA}}$}

$1 \operatorname{Reg} 19$

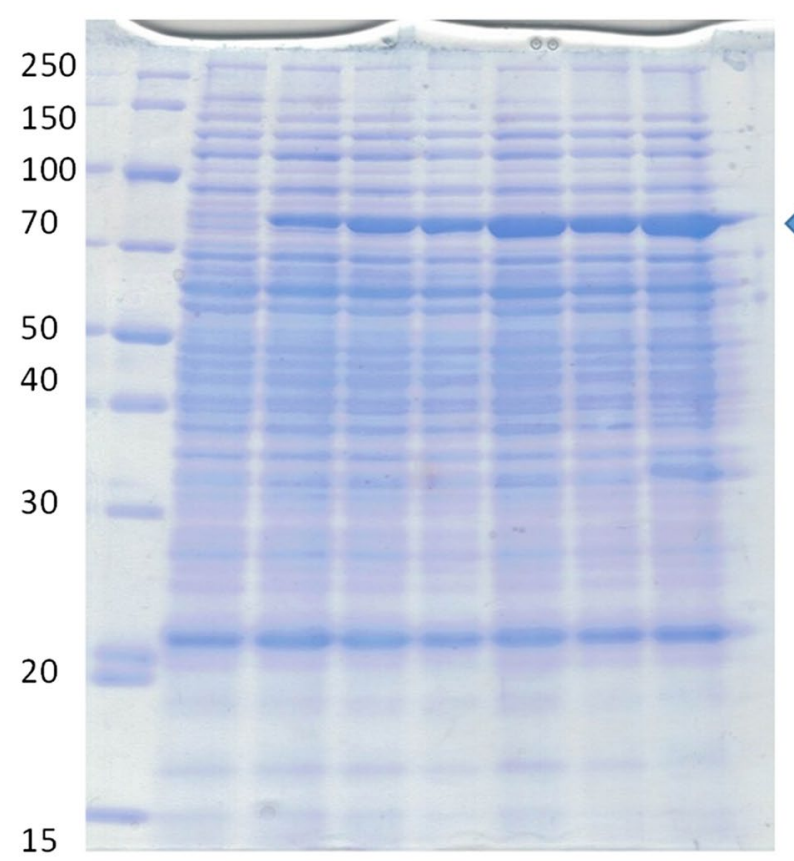

\section{$\begin{array}{llllllll}M & 1 & 2 & 3 & 4 & 5 & 6 & 7\end{array}$}

Fig. 4 SDS-PAGE showing the protein crude extracts from REG19, JA-Bs34 to JA-Bs40 and from REG19 carrying the plasmid pHWG1132. Crude extracts were prepared from cells induced by glucitol for $16 \mathrm{~h}$, cleared by centrifugation and the amount of $15 \mu \mathrm{g}$ cleared crude extract proteins were applied on the SDS-gel in each line. The GanA protein of $79.8 \mathrm{kDa}$ is indicated by the arrow

selection of the plasmid was compared. Overnight cultures of both strains in LB with $0.5 \%$ glucose and in case of REG19/pHWG1132 with glucose and kanamycin were diluted $1: 1000$ in LB with $0.5 \%$ glucitol. The cells were grown in shaking flasks at $37^{\circ} \mathrm{C}$ to stationary phase and diluted again 1000-fold. This was repeated three times and each time when the stationary phase was reached, the $\beta$-galactosidase activity was determined. The results are presented in Fig. 5. The strain JA-Bs40 continuously produced about the same amount of GanA over the time. In contrast, REG19/ pHWG1132 showed only about $20 \%$ of GanA activity even after the first round of growth to stationary phase corresponding to about nine generations without antibiotic supplementation. The GanA activity decreased continuously from dilution to dilution and was nearly not detectable at the end of the last round of growth. When the cells from this last round were plated to single colonies on LB agar plates and tested for kanamycin resistance, none of the 70 colonies checked were able to grow on LB agar plates supplemented with kanamycin. This demonstrated the high frequency of plasmid loss.

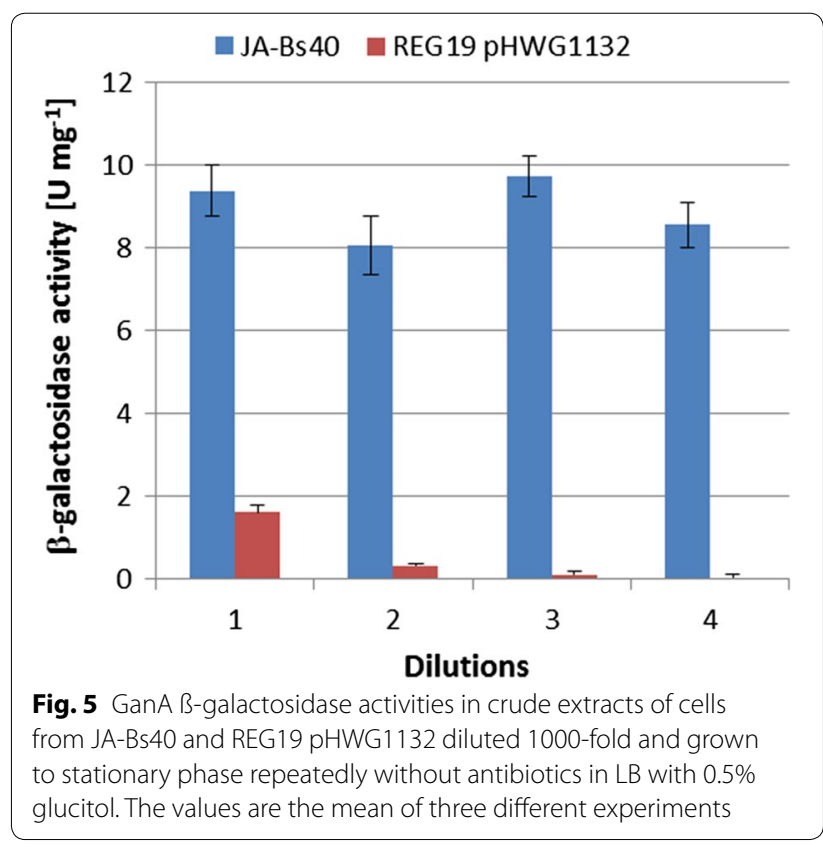




\section{Discussion}

The use of multi-copy expression vectors for heterologous protein production is straightforward and needs only one cloning step and one transformation procedure to get a suitable production strain. The disadvantage of these vector systems are its instability (Fleming and Patching 1994; Shoham and Demain 1991) as it was demonstrated here with the pUB110 derivative pHWG1132 for production of GanA. Under induced expression conditions it needed the presence of an appropriate antibiotic to select for cells still carrying the plasmids and producing GanA in high amounts. This is in contrast to the strains with multiple integrations of expression cassettes. They are tedious to construct but need no longer antibiotics. The use of the CRISPR/Cas9 system is especially useful since integration is selected due to the double-strand cut of the target site and repair by homologous recombination. With traditional methods, integration is selected via an antibiotic resistance gene which has to be removed in a second procedure (Bloor and Cranenburgh 2006; Sanchez et al. 2007; Sanchis et al. 1997). Such methods usually leave behind recognition sites for recombinases causing maybe problems in the next rounds of insertions.

For successful insertions into the chromosome, the expression cassette has to be flanked by sequences of several hundred base pairs length obtained from both sides of the target region. Such insertion cassettes can be constructed in a traditional way by cloning first the expression cassette into a polylinker sequence of a vector and then adding upstream and downstream sequences from the target. As shown in this report, the procedure can be reduced to one cloning step by using the $S f i$ sites in the CRISPR/Cas9 vector pJOE8999 and the SfiI sites added to the fragments by PCR. They allowed an ordered ligation of the PCR fragments with the vector in one step. Alternatives would by the alignment of vector and fragments with overlapping ends by Gibson assembly or by PCR.

The multiple gene integration procedure can also be used to remove unwanted properties of the strain like proteases (Zhang et al. 2019), prophages, antibiotic biosynthesis or sporulation. Even the deletion of the many putative genes of unknown function might be of advantage by reducing the metabolic burden of the cells (Manabe et al. 2012; Morimoto et al. 2008).

How many genes have to be integrated into the chromosome to get a maximal yield of protein depends on many parameters like promoter strength, translation efficiency, mRNA and protein stability etc. Locations nearer to the replication origin increases the average copy number in replicating cells and transcription in the same orientation as the replication fork moves on the chromosome avoids collisions with the replication machinery (Jeong et al. 2018; Sauer et al. 2016).

Taking in account the specific activity of a purified GanA protein of $80 \mathrm{U} / \mathrm{mg}$ with pNP- $\beta$ Gal as substrate (Watzlawick et al. 2016) the productivity of GanA with JA-Bs40 and Reg19/pHWG1132 is about 10\% of their total soluble cell protein. This yield was also judged by SDS-PAGE of soluble GanA in cleared crude extracts. SDS-PAGE analysis of the cell pellet fraction showed no presence of an unsoluble GanA protein band. The production of soluble target proteins in Bacillus up to $30 \%$ of the cell proteins were reported by using other expression systems for the respective genes (Phan et al. 2015). In case of the obtained results during the expression of the $\operatorname{gan} A$ gene in this study, it is still not clear what limits ganA expression to get similar high amounts. It certainly is not the copy number of the expression cassettes since pUB110 is present at 48 copies per cell (Leonhardt 1990). Since $P_{\text {gut }}$ needs the activator protein GutR that is located as a single copy on the chromosome, one could speculate that there is not enough activator produced. In consequence, the cloning of the gutR gene into the expression cassettes might lead to a further increase of GanA production.

In summary, the use of the CRISPR/Cas9 vectors to construct stable production strains for overproduction of enzymes and other proteins by multiple gene integration is a valuable, fast and easy to handle system. It avoids the presence of an antibiotic resistance gene and allows at the same time the improvement of the production strains by removal of unwanted properties.

\section{Acknowledgements}

We thank Annette Schneck for excellent technical assistance throughout the study.

\section{Authors' contributions}

JA planned the experiments and constructed the Bacillus subtilis strains. HW significantly contributed to conception and interpretation of the experiments. Both authors read and approved the final manuscript.

Funding

The work was funded by university budget funds.

Availability of data and materials

Please turn to the authors for all requests.

Ethics approval and consent to participate

This article does not contain any studies with human participants or animals performed by any of the authors.

Consent for publication

Not applicable.

Competing interests

The authors declare that they have no competing interests. 
Received: 4 August 2019 Accepted: 21 September 2019 Published online: 30 September 2019

\section{References}

Aguilar Suárez R, Stülke J, van Dijl JM (2019) Less is more: toward a genomereduced Bacillus cell factory for "Difficult Proteins". ACS Synth Biol 8:99-108. https://doi.org/10.1021/acssynbio.8b00342

Altenbuchner J (2016) Editing of the Bacillus subtilis genome by the CRISPR-Cas9 system. Appl Environ Microbiol 82:5421-5427. https://doi. org/10.1128/AEM.01453-16

Altenbuchner J, Viell P, Pelletier I (1992) Positive selection vectors based on palindromic DNA sequences. Methods Enzymol 216:457-466

Barbe V, Cruveiller S, Kunst F, Lenoble P, Meurice G, Sekowska A, Vallenet D, Wang T, Moszer I, Médigue C, Danchin A (2009) From a consortium sequence to a unified sequence: the Bacillus subtilis 168 reference genome a decade later. Microbiology 155:1758-1775. https://doi. org/10.1099/mic.0.027839-0

Bloor AE, Cranenburgh RM (2006) An efficient method of selectable marker gene excision by Xer recombination for gene replacement in bacterial chromosomes. Appl Environ Microbiol 72:2520-2525. https://doi. org/10.1128/AEM.72.4.2520-2525.2006

Bradford MM (1976) A rapid and sensitive method for the quantitation of microgram quantities of protein utilizing the principle of proteindye binding. Anal Biochem 72:248-254. https://doi.org/10.1006/ abio.1976.9999

Brockmeier U, Wendorff M, Eggert T (2006) Versatile expression and secretion vectors for Bacillus subtilis. Curr Microbiol 52:143-148. https://doi. org/10.1007/s00284-005-0231-7

Burby PE, Simmons LA (2017) CRISPR/Cas9 editing of the Bacillus subtilis genome. Bio-Protocol. https://doi.org/10.21769/bioprotoc.2272

Cai D, Rao Y, Zhan Y, Wang Q, Chen S (2019) Engineering Bacillus for efficient production of heterologous protein: current progress, challenge and prospect. J Appl Microbiol 126:1632-1642. https://doi.org/10.1111/ jam.14192

Chen I, Dubnau D (2004) DNA uptake during bacterial transformation. Nat Rev Microbiol 2:241-249. https://doi.org/10.1038/nrmicro844

Claverys J-P, Prudhomme M, Martin B (2006) Induction of competence reguIons as a general response to stress in gram-positive bacteria. Annu Rev Microbiol 60:451-475. https://doi.org/10.1146/annurev.micro.60.08080 5.142139

Commichau FM, Pietack N, Stülke J (2013) Essential genes in Bacillus subtilis: a re-evaluation after ten years. Mol BioSyst 9:1068-1075. https://doi. org/10.1039/c3mb25595f

de Boer Sietske A, Diderichsen B (1991) On the safety of Bacillus subtilis and B. amyloliquefaciens: a review. Appl Microbiol Biotechnol 36:1-4. https://doi. org/10.1007/BF00164689

Fleming GT, Patching JW (1994) Plasmid instability in an industrial strain of Bacillus subtilis grown in chemostat culture. J Ind Microbiol 13:106-111. https://doi.org/10.1007/BF01584107

Görke B, Stülke J (2008) Carbon catabolite repression in bacteria: many ways to make the most out of nutrients. Nat Rev Microbiol 6:613-624. https://doi. org/10.1038/nrmicro1932

Heravi KM, Watzlawick H, Altenbuchner J (2015) Development of an anhydrotetracycline-inducible expression system for expression of a neopullulanase in B. subtilis. Plasmid 82:35-42. https://doi.org/10.1016/j. plasmid.2015.10.002

Hong K-Q, Liu D-Y, Chen T, Wang Z-W (2018) Recent advances in CRISPR/Cas9 mediated genome editing in Bacillus subtilis. World J Microbiol Biotechnol 34:153. https://doi.org/10.1007/s11274-018-2537-1

Huang K, Zhang T, Jiang B, Yan X, Mu W, Miao M (2017) Overproduction of Rummeliibacillus pycnus arginase with multi-copy insertion of the argR-pyc cassette into the Bacillus subtilis chromosome. Appl Microbiol Biotechnol 101:6039-6048. https://doi.org/10.1007/s00253-017-8355-9

Jalanko A, Palva I, Söderlund H (1981) Restriction maps of plasmids pUB110 and pBD9. Gene 14:325-328. https://doi.org/10.1016/03781119(81)90165-7

Janniere L, Niaudet B, Pierre E, Ehrlich SD (1985) Stable gene amplification in the chromosome of Bacillus subtilis. Gene 40:47-55
Jeong KJ, Park IY, Kim MS, Kim SC (1998) High-level expression of an endoxylanase gene from Bacillus sp. in Bacillus subtilis DB104 for the production of xylobiose from xylan. Appl Microbiol Biotechnol 50:113-118. https://doi. org/10.1007/s002530051264

Jeong D-E, So Y, Park S-Y, Park S-H, Choi S-K (2018) Random knock-in expression system for high yield production of heterologous protein in Bacillus subtilis. J Biotechnol 266:50-58. https://doi.org/10.1016/j.jbiot ec.2017.12.007

Kiel JA, ten Berge AM, Borger P, Venema G (1995) A general method for the consecutive integration of single copies of a heterologous gene at multiple locations in the Bacillus subtilis chromosome by replacement recombination. Appl Environ Microbiol 61:4244-4250

Kostner D, Rachinger M, Liebl W, Ehrenreich A (2017) Markerless deletion of putative alanine dehydrogenase genes in Bacillus licheniformis using a codBA-based counter selection technique. Microbiology 163:1532-1539. https://doi.org/10.1099/mic.0.000544

Kramer N, Hahn J, Dubnau D (2007) Multiple interactions among the competence proteins of Bacillus subtilis. Mol Microbiol 65:454-464. https://doi. org/10.1111/j.1365-2958.2007.05799.x

Laemmli UK (1970) Cleavage of structural proteins during the assembly of the head of bacteriophage T4. Nature 227:680-685. https://doi. org/10.1038/227680a0

Leonhardt H (1990) Identification of a low-copy-number mutation within the pUB110 replicon and its effect on plasmid stability in Bacillus subtilis. Gene 94:121-124

Liu L, Liu Y, Shin H-D, Chen RR, Wang NS, Li J, Du G, Chen J (2013) Developing Bacillus spp. as a cell factory for production of microbial enzymes and industrially important biochemicals in the context of systems and synthetic biology. Appl Microbiol Biotechnol 97:6113-6127. https://doi. org/10.1007/s00253-013-4960-4

Manabe K, Kageyama Y, Tohata M, Ara K, Ozaki K, Ogasawara N (2012) High external pH enables more efficient secretion of alkaline a-amylase AmyK38 by Bacillus subtilis. Microb Cell Fact 11:74. https://doi. org/10.1186/1475-2859-11-74

Manabe K, Kageyama Y, Morimoto T, Shimizu E, Takahashi H, Kanaya S, Ara K, Ozaki K, Ogasawara N (2013) Improved production of secreted heterologous enzyme in Bacillus subtilis strain MGB874 via modification of glutamate metabolism and growth conditions. Microb Cell Fact 12:18. https://doi.org/10.1186/1475-2859-12-18

Meissner L, Kauffmann K, Wengeler T, Mitsunaga H, Fukusaki E, Büchs J (2015) Influence of nitrogen source and $\mathrm{pH}$ value on undesired poly( $\gamma$-glutamic acid) formation of a protease producing Bacillus licheniformis strain. J Ind Microbiol Biotechnol 42:1203-1215. https://doi.org/10.1007/s1029 5-015-1640-7

Mori M, Hashiguchi K, Yoda K, Yamasaki M (1988) Designed gene amplification on the Bacillus subtilis chromosome. J Gen Microbiol 134:85-95. https:// doi.org/10.1099/00221287-134-1-85

Morimoto T, Kadoya R, Endo K, Tohata M, Sawada K, Liu S, Ozawa T, Kodama T, Kakeshita H, Kageyama Y, Manabe K, Kanaya S, Ara K, Ozaki K, Ogasawara $\mathrm{N}$ (2008) Enhanced recombinant protein productivity by genome reduction in Bacillus subtilis. DNA Res 15:73-81. https://doi.org/10.1093/dnare s/dsn002

Motejadded $\mathrm{H}$, Altenbuchner J (2007) Integration of a lipase gene into the Bacillus subtilis chromosome: recombinant strains without antibiotic resistance marker. Iran J Biotechnol 5:105-109

Petit MA, Joliff G, Mesas JM, Klier A, Rapoport G, Ehrlich SD (1990) Hypersecretion of a cellulase from Clostridium thermocellum in Bacillus subtilis by induction of chromosomal DNA amplification. Biotechnology (NY) 8:559-563

Petit MA, Mesas JM, Noirot P, Morel-Deville F, Ehrlich SD (1992) Induction of DNA amplification in the Bacillus subtilis chromosome. EMBO J 11:1317-1326

Phan TTP, Tran LT, Schumann W, Nguyen HD (2015) Development of Pgrac100based expression vectors allowing high protein production levels in Bacillus subtilis and relatively low basal expression in Escherichia coli. Microb Cell Fact 14:72. https://doi.org/10.1186/s12934-015-0255-z

Poon KK, Chu JC, Wong SL (2001) Roles of glucitol in the GutR-mediated transcription activation process in Bacillus subtilis: glucitol induces GutR to change its conformation and to bind ATP. J Biol Chem 276:29819-29825. https://doi.org/10.1074/jbc.M100905200 
Rahmer R, Morabbi Heravi K, Altenbuchner J (2015) Construction of a supercompetent Bacillus subtilis 168 using the Pmt/A-comKS inducible cassette. Front Microbiol 6:1431. https://doi.org/10.3389/fmicb.2015.01431

Reuß DR, Altenbuchner J, Mäder U, Rath H, Ischebeck T, Sappa PK, Thürmer A, Guérin C, Nicolas P, Steil L, Zhu B, Feussner I, Klumpp S, Daniel R, Commichau FM, Völker U, Stülke J (2017) Large-scale reduction of the Bacillus subtilis genome: consequences for the transcriptional network, resource allocation, and metabolism. Genome Res 27:289-299. https:// doi.org/10.1101/gr.215293.116

Sambrook J, Russell DW (2001) Molecular cloning: a laboratory manual, 3rd edn. Cold Spring Harbor Laboratory, Cold Spring Harbor

Sanchez H, Cozar MC, Martinez-Jimenez MI (2007) Targeting the Bacillus subtilis genome: an efficient and clean method for gene disruption. J Microbiol Methods 70:389-394. https://doi.org/10.1016/j.mimet.2007.05.004

Sanchis V, Agaisse H, Chaufaux J, Lereclus D (1997) A recombinase-mediated system for elimination of antibiotic resistance gene markers from genetically engineered Bacillus thuringiensis strains. Appl Environ Microbiol 63:779-784

Sauer C, Syvertsson S, Bohorquez LC, Cruz R, Harwood CR, van Rij T, Hamoen LW (2016) Effect of genome position on heterologous gene expression in Bacillus subtilis: an unbiased analysis. ACS Synth Biol 5:942-947. https:// doi.org/10.1021/acssynbio.6b00065

Schallmey M, Singh A, Ward OP (2004) Developments in the use of Bacillus species for industrial production. Can J Microbiol 50:1-17. https://doi. org/10.1139/w03-076

Schumann W (2007) Production of recombinant proteins in Bacillus subtilis. In: Laskin Al, Sariaslani S, Gadd GM (eds) Advances in applied microbiology, vol 62. Academic Press, San Diego, pp 137-189

Shoham Y, Demain AL (1991) Kinetics of loss of a recombinant plasmid in Bacillus subtilis. Biotechnol Bioeng 37:927-935. https://doi.org/10.1002/ bit.260371006

Slugeňová M, Bukovská G, Turňa J, Timko J (1993) Enhanced alpha-amylase production by chromosomal integration of pTVA1 in industrial strain in Bacillus subtilis. Biotechnol Lett 15:483-488. https://doi.org/10.1007/ BF00129323

Stemmer M, Thumberger T, Del Sol Keyer M, Wittbrodt J, Mateo JL (2015) CCTop: an intuitive, flexible and reliable CRISPR/Cas9 target prediction tool. PLoS ONE 10:e0124633. https://doi.org/10.1371/journal.pone.01246 33

Tanaka K, Henry CS, Zinner JF, Jolivet E, Cohoon MP, Xia F, Bidnenko V, Ehrlich SD, Stevens RL, Noirot P (2013) Building the repertoire of dispensable chromosome regions in Bacillus subtilis entails major refinement of cognate large-scale metabolic model. Nucleic Acids Res 41:687-699. https:// doi.org/10.1093/nar/gks963

Terpe K (2006) Overview of bacterial expression systems for heterologous protein production: from molecular and biochemical fundamentals to commercial systems. Appl Microbiol Biotechnol 72:211. https://doi. org/10.1007/s00253-006-0465-8

van der Laan JC, Gerritse G, Mulleners LJ, van der Hoek RA, Quax WJ (1991) Cloning, characterization, and multiple chromosomal integration of a Bacillus alkaline protease gene. Appl Environ Microbiol 57:901-909

Vázquez-Cruz C, Ochoa-Sánchez JC, Olmedo-Alvarez G (1996) Pulse-field gelelectrophoretic analysis of the amplification and copy-number stability of an integrational plasmid in Bacillus subtilis. Appl Microbiol Biotechnol 46:55-60

Wang J-J, Rojanatavorn K, Shih JCH (2004) Increased production of Bacillus keratinase by chromosomal integration of multiple copies of the ker $A$ gene. Biotechnol Bioeng 87:459-464. https://doi.org/10.1002/bit.20145
Watzlawick H, Morabbi Heravi K, Altenbuchner J (2016) Role of the gan$S P Q A B$ operon in degradation of galactan by Bacillus subtilis. J Bacteriol 198:2887-2896. https://doi.org/10.1128/JB.00468-16

Wenzel M, Altenbuchner J (2015) Development of a markerless gene deletion system for Bacillus subtilis based on the mannose phosphoenolpyruvatedependent phosphotransferase system. Microbiology 161:1942-1949. https://doi.org/10.1099/mic.0.000150

Wenzel M, Müller A, Siemann-Herzberg M, Altenbuchner J (2011) Self-inducible Bacillus subtilis expression system for reliable and inexpensive protein production by high-cell-density fermentation. Appl Environ Microbiol 77:6419-6425. https://doi.org/10.1128/AEM.05219-11

Westbrook AW, Moo-Young M, Chou CP (2016) Development of a CRISPRCas9 tool kit for comprehensive engineering of Bacillus subtilis. Appl Environ Microbiol 82:4876-4895. https://doi.org/10.1128/AEM.01159-16

Xia Y, Chen W, Zhao J, Tian F, Zhang H, Ding X (2007) Construction of a new food-grade expression system for Bacillus subtilis based on theta replication plasmids and auxotrophic complementation. Appl Microbiol Biotechnol 76:643-650. https://doi.org/10.1007/s00253-007-1035-4

Yanisch-Perron C, Vieira J, Messing J (1985) Improved M13 phage cloning vectors and host strains: nucleotide sequences of the M13mp18 and pUC19 vectors. Gene 33:103-119

Ye R, Wong SL (1994) Transcriptional regulation of the Bacillus subtilis glucitol dehydrogenase gene. J Bacteriol 176:3314-3320. https://doi.org/10.1128/ jb.176.11.3314-3320.1994

Ye R, Rehemtulla SN, Wong SL (1994) Glucitol induction in Bacillus subtilis is mediated by a regulatory factor, GutR. J Bacteriol 176:3321-3327. https:// doi.org/10.1128/jb.176.11.3321-3327.1994

Yomantas YA, Abalakina EG, Golubeva LI, Gorbacheva LY, Mashko SV (2011) Overproduction of Bacillus amyloliquefaciens extracellular glutamyl-endopeptidase as a result of ectopic multi-copy insertion of an efficientlyexpressed mpr gene into the Bacillus subtilis chromosome. Microb Cell Fact 10:64. https://doi.org/10.1186/1475-2859-10-64

Young M (1984) Gene amplification in Bacillus subtilis. J Gen Microbiol 130:1613-1621. https://doi.org/10.1099/00221287-130-7-1613

Zakataeva NP, Nikitina OV, Gronskiy SV, Romanenkov DV, Livshits VA (2010) A simple method to introduce marker-free genetic modifications into the chromosome of naturally nontransformable Bacillus amyloliquefaciens strains. Appl Microbiol Biotechnol 85:1201-1209. https://doi.org/10.1007/ s00253-009-2276-1

Zhang X-Z, Yan X, Cui Z-L, Hong Q, Li S-P (2006) mazF, a novel counter-selectable marker for unmarked chromosomal manipulation in Bacillus subtilis. Nucleic Acids Res 34:e71. https://doi.org/10.1093/nar/gkl358

Zhang X, Xu Z, Liu S, Qian K, Xu M, Yang T, Xu J, Rao Z (2019) Improving the production of salt-tolerant glutaminase by integrating multiple copies of Mglu into the protease and 16S rDNA genes of Bacillus subtilis 168 . Molecules. https://doi.org/10.3390/molecules 24030592

Zhu B, Stülke J (2018) SubtiWiki in 2018: from genes and proteins to functional network annotation of the model organism Bacillus subtilis. Nucleic Acids Res 46:D743-D748. https://doi.org/10.1093/nar/gkx908

\section{Publisher's Note}

Springer Nature remains neutral with regard to jurisdictional claims in published maps and institutional affiliations. 